\title{
Level of Augmentative and Alternative Communication Knowledge and Skills among Special Education Teachers for Autistic Students in Primary School
}

\author{
Shuhada Abdul Ghani, Suziyani Mohamed \\ National University of Malaysia, 43600 Bangi, Selangor, Malaysia. \\ Email: shuhada@siswa.ukm.edu.my
}

\begin{abstract}
Supplementary and replacement communication or augmentative and alternative communication (AAC) is needed to replace the voices of autistic pupils who have difficulty communicating throughout the learning and facilitating process (PdPC) in the classroom. The teacher's proficiency in communication skills can enhance and develop positive learning behaviours of autistic pupils throughout the learning process. This research aims to identify augmentative and alternative communication skills among special education teachers for autistic pupils in the classroom. A total of 73 special education teachers throughout Malaysia were selected as the respondents for thy research. The data obtained in the form of percentage shows the knowledge and skills of teachers in implementing AAC. Overall, this research shows that the level of knowledge and skills of teachers in implementing AAC in the classroom is still moderate and requires training.
\end{abstract}

Keywords: knowledge, skills, augmentative and alternative communication, autism

\section{INTRODUCTION}

United States National Research Council (2001), formulated strategies by providing support, and augmentative and assistive tools to meet the needs of special needs pupils (Tobergte \& Curtis, 2013). This education policy was entrusted to special education teachers throughout the country to implement these skills during the PdPC process at the schools. This policy is in line with the approach of the Malaysia Education Blueprint 2013-2025 that assigns a great role to the teachers as a leader in the classroom. The teachers need to provide a good example to their students, and often serve as a role model for young people (Blueprint, 2013). Students with verbal communication problems have two difficulties regarding language. First, they cannot express what they want to communicate through the speech; and second; they have difficulty to understand the speech of others. If this situation cannot be traced at the beginning of schooling, they will be left behind in their education. They will also be left behind in many other aspects related to verbal communication. It makes it difficult for these pupils to live a good social life with their peers at school (Jang et al., 2011). Autistic pupils experience communication difficulties at home and school. It complicates and restricts their positive behaviour in delivering their wants. According to American Psychiatric Association (2016), autism is defined as mix inability, and it is usually seen among children below 12 years old. This condition is caused by the effects of neurological disorders that interfere with brain function. This situation will make it difficult for them to live their daily life at home and at school.
According to Mustonen et al. (1991), augmentative and alternative communications are the methods and tools that can enhance existing verbal communication skills. Thus, students with communication problems including speech need specific learning attention. Council (2001), classified communication disability intoe two main divisions that aree attention merger and use of symbol. While Porter (2002) and Kuder (2003) classified AAC into non-verbal and verbal to replace sound and voice, social difficulties, communication disabilities and behavioural problems. American Speech-Language-Hearing Association defined AAC as a form of communication using gestures, sign language, electronic devices, photographs, speech instruments or written communications.

A study on the communication of autistic individuals has been done over the past ten years. Data released by the Malaysian Psychiatric Association in 2008 estimated that 1 out of 500 children in Malaysia had autism spectrum disorder and statistics shows that about 47,000 Malaysians had autism. Of these, 4 or 5 people of 10,000 patients were experiencing pure autism that results in loss of ability to understand the surroundings but themselves, and this number is expected to grow year by year. Almost $(70 \%)$ of children with autism have a problem of mental retardation at different levels, causing their learning process to be slow, difficult to interact, experiencing communication disorders and having behavioural problems.

The AAC method has been widely practised in developed countries, and the outcome demonstrates a great improvement in the learning behaviour progress of autisticsstudents. According to Sigafoos \& Mirenda (2002), AAC components include communication 
techniques, symbol systems and communication skills by the needs of students. Various AAC methods can be used including non-aided AAC such as sign language, body movement, facial expression and fingerspell, and aided AAC that is communication using additional tools such as pictorial communication systems and high-tech communication systems (Ganz, 2014).

Non aided AAC communication techniques do not require external and mobile support tools. This technique utilises methods such as speeches, sign language, gestures and facial expressions. It requires the ability, memory, sign language skills and creativity that sometimes it is difficult to learn. Light \& Drager (2002), stated that aided AAC is a technique that utilised support tools and requires detailed procedures for its maintenance. The support tools range from simple to sophisticated electronic devices that have a complex system. This technique requires real devices such as laptops, cell phones, iPads, iPods, go talks, hip talks, partner 4, tech talk, tech scan and voicePal Pro. This technique is also easy to use and easy to fit according to the difficulty and ability level of thesstudents. It can generate more complex messages than the user's language capabilities and can communicate from a distance (Zlatanova, 2002; Kuder, 2003).

There are many communication aids available in the classroom but are not utilised due to lack of awareness, no initiative or lack of creativity among teachers (Pilgrim, Bledsoe, \& Reily, 2012). Undoubtedly, educating special needs children is very challenging and demands a high level of patience and commitment from the teachers (Hamzah, 2014) thus to attract the interest of autistic pupils with various behavioural problems to study is a challenging task. Not all teachers were exposed to the use of sign language and pictures as a communication mode and consequently impact student learning (Aini \& Hanifah, 2015). In addition to behavioural and communication problems, autistic students show progress regarding motor, cognitive, and social developments. Their ability in self-reliance is different from other normal children.

Students with disabilities who are in this special education class have a better chance of success following to the module provided such as collaborative learning, co-operative teaching, peer guidance and innovative educational system scheduling implemented comprehensively in the classroom (Abbeduto et al., 2004). Autistic students have a different behavioural disorder from normal students. They experienced complex developmental issues regarding socialisation, behaviour and communication skills. They usually cannot get along with other students and often cause behavioural problems. Some autistic students never communicate and do not want to follow the learning process in the classroom. When an identified autistic student fails to speak and communicate properly, intervention and alternative augmentative communication skills are required to improve communication skills (Son et al., 2006) both ACC systems were simultaneously available and the child could select which one of the two systems to use. There was little difference between pictureexchange and VOCA in terms of acquisition rates. Two children demonstrated a consistent preference for picture-exchange and the third showed a preference for the VOCA. Both speed of acquisition and system preference should be considered when designing AAC interventions for children with autism and related developmental disabilities.

It is impossible to achieve PdPC without effective communication in the classroom (Cooper \& Simonds, 2007). Some of the autistic pupils sleep all day in the classroom without following any learning activities, and this is very detrimental to the potential that should be polished among them. Noraini, Zamri, \& Zahara (2012), also pointed out that most teachers at integrated special education for learning difficulties class (PPKI) do not receive extensive training and exposure to address the communication skills problem between the teachers and the pupils. This finding is supported by Ghani and Ahmad (2014) that stated autistic students usually have communication disorders, problems in social interactions, sensory disorders, play patterns disruption and emotional behaviours. According to the American Psychiatric Association (2016), these autism disorders range from three main areas of stereotyping and restricted social interaction, communication and behavioural distortion.

It is imperative for a special education teacher to understand and apply the appropriate communication methods during the PdPC, including the use of technology appropriate to the learning needs of learners with learning difficulties (Rabi, 2015). This study decided on two research objectives: (i) To identify the level of AAC communication knowledge and skills among teachers of learning difficulties special education; (ii) To identify the level of AAC communication teaching skills among teachers of learning difficulties special education

\section{METHOD}

This research adopted a survey methodology to identify the level of AAC communication knowledge and skills among the special education teachers. According to Creswell and Creswell (2017), a study conducted using the survey method can collect data directly from the subjects and could generalise the population. A survey using a questionnaire instrument was chosen because it is easy to administer and easy to process. 
Table 1. ACC Knowledge Items among teachers of integrated special education for learning difficulties

\begin{tabular}{llcc}
\hline No. & Items & Yes (\%) & No (\%) \\
\hline 1. & Able to differentiate between augmentative and alternative communications & 53 & 47 \\
2. & Understands augmentative communication as a replacement communication & 68 & 32 \\
3. & Understands augmentative communication as a supplement communication & 72 & 28 \\
4. & Understands that AAC can be implemented without assistance (unaided) & 33 & 67 \\
5. & Understands that AAC can be implemented with assistance (aided) & 54 & 46 \\
6. & Understands that aided AAC can be implemented using low technology & 56 & 44 \\
7. & Understands that aided AAC can be implemented in the classroom & 64 & 36 \\
8. & Understands that unaided AAC can be implemented outside the classroom & 56 & 44 \\
9. & Understands the use of smartphones & 97 & 3 \\
10. & Understands the use of iPad & 79 & 21 \\
11. & Understands the use of laptop & 97 & 3 \\
12. & Understands the use of Go-Talk & 32 & 68 \\
13. & Understands the use of communication boards & 56 & 44 \\
14. & Understands the use of communication books & 64 & 36 \\
15. & Understands the use of the Picture Exchange Communication System (PECS) & 50 & 50 \\
16. & Proficient in searching for information using the Internet & 95 & 5 \\
17. & Proficient in using Google application to look for pictures & 95 & 5 \\
18. & Proficient in uploading pictures online & 90 & 10 \\
19. & Proficient in uploading audio online & 71 & 29 \\
20. & Proficient in uploading videos online & 76 & 24 \\
21. & Proficient in uploading videos using YouTube & 72 & 28 \\
\hline
\end{tabular}

\section{FINDINGS AND DISCUSSION}

\section{Findings}

AAC is a method that anyone can use including individuals who cannot speak or have speech problems (Millar, Light, \& Schlosser, 2006). The AAC is a communication method that can be used to analyse the effectiveness and outcomes of its implementation in the classroom (Santrock, 2011). This study looked at the knowledge level of special education teachers in obtaining the best teaching skills method throughout the PdPC process. If the students with verbal communication difficulties can be identified early, teachers can plan and provide alternative communication to get them engaged and gain understanding during PdPC (Harding et al., 2011).

This section discusses the findings of questionnaires that answer questions related to augmentative and alternative communication knowledge among teachers of integrated learning difficulties special education. Findings are detailed out in Table 1.

Findings from the questionnaire showed an increase in internet knowledge (95\%), proficiency in using the laptop (97\%) and smartphones (97\%). However, $(47 \%)$ of special education teachers were still not able to differentiate between augmentative and alternative communication while only (33\%) understood that AAC can be implemented without using technology assistance in the classroom. A total of $(68 \%)$ of the teachers were not aware of Go-Talk as one of the tools that can be used in aided AAC methods as the communication aid and only $(50 \%)$ of the teachers were using the Picture Exchange Communication System (PECS) that has been proven to help communication and behavioural problems among autistic pupils. The findings from the questionnaire showed that knowledge and skills limitation of special education teachers were due to their dependency on laptops and internet search for implementing $\mathrm{AAC}$ in the classroom.

\section{Discussion}

United States National Research Council (2001) found that teacher training is the weakest element in the effort to provide effective services for autistic students. Improper teacher training is also a major issue that hinders the provision of adequate and well-trained teachers in the field of education for autistic students. Students with Autism Spectrum Disorder (especially classic autism) are not easy to educate. They are less 
likely to benefit from conventional education systems and special education methods that may be inadequate.

According to Hasnah et al. (2010), lack of knowledge on autism amongst special education teachers is believed to be due to the lack of comprehensive inputs received throughout the education training program during university or institute studies. The findings show that most of the special education teachers mentioned that the training received for recognising autism characteristics, assessing autistic students, conducting teaching strategies for autistic students, undergoing a hands-on experience with these children and collaborating with other professionals and parents are insufficient. Similar results are also found in the research conducted by Subihi (2013) in which there was inadequacy of the student teachers' knowledge of AAC. Therefore, special education teachers need to do their training to master autism modules that include social skills, communication, self-knowledge, support strategies, behavioural management and intervention.

This research examines how primary school special education teachers apply AAC teaching skills in the classroom to address the communication problem of autistic students. In the aspect of learning and facilitating, the ability of students to get the maximum knowledge, the progress will depend on the teachers' and students' ability to master effective communication (Sakinah \& Nurdin, 2014; Rabi, 2015). There are four recommended AAC competencies suggested by Da Fonte \& Boesh (2016) consisting of communication development and communicative competencies, teamwork and collaborative practices, role and functions of AAC systems, and AAC assessment and instructional strategies.

Statistical data report by Centre for Disease and Control Prevention on autistic students released in the United States in 2010 showed that 1 in 110 children were experiencing autism (Toran \& Bujang, 2013). This situation increased dramatically within five years, and the latest data in 2015 showed an increase of 1 in 68 children who have been diagnosed with autism. A study by Hazahamima and Norshidah (2016) found that autistic students were not interested in traditional PdPC sessions conducted in the classroom. They were found to have ignored the PdPC sessions by demonstrating challenging behaviours such as walking, quivering hands, daydreaming and crying. It has become a requirement for a special education teacher to equip themselves with optimum communication skills to help to make PdPC effective both inside and outside the classroom (Sakinah \& Nurdin, 2014).

Lack of knowledge of autistic students among teachers complicates the efficient teaching and learning process. Some teachers are labelling the autistic students as stupid because they lack knowledge on how to approach them. Almost all autism cases among students experience social interaction disorders, communication skills and imagination problems. Therefore, the progress of these autistic students is slower than normal students. However, the degree of disorder of an autistic individual differs from the other.

Effectivelearningneeds for autistic students involve appropriate behaviour control, and communication and social skills. Frequent problem happening inside the classroom during the PdPC process are undeveloped communication, and uncontrolled action and behaviour (Trevarthen et al., 1996). There are certain conditions for which autistic pupils cannot speak even when they communicate well, and that is called 'mutism' (Sakinah \& Nurdin, 2014). These autistic students require teachers with unique teaching skills to assist and provide them with the most basic support skills in the aspects of communication, socialisation and behaviour (Alexander, Ayres, \& Smith, 2015)the authors include 23 studies where researchers experimentally evaluated training for teachers of students with Autism Spectrum Disorder (ASD. Therefore, the communication skills of these students need to be stimulated and to assist them to create interest to follow through the PdPC session.

Lack of awareness and appropriate teaching techniques among teachers may affect students' achievement. Hence it is important for teachers to understand the appropriate teaching skills to the autistic students to start the PdPC session and to understand their learning behaviour while in the classroom. The use of augmentative and alternative communication technique such as swapping of pictures, sign language and gestures during PdPC can be developed through a series of formal training and workshops. Teachers who apply effective communication methods and techniques will encourage and help the pupils to clarify the message they want to convey. Through this study, the researcher assessed how AAC communication knowledge and skills mastery among special education teachers during the PdPC session in the classroom could address the communication problems of autistic pupils.

\section{CONCLUSION}

Augmentative and alternative communication skills mastery among teachers can help to improve the communication difficulties among students with learning problems, especially autistic students who have speech problems during PdPC session in the classroom. Aided and non-aided AAC communication skills mastery cover the whole aspect of verbal and non-verbal communication. AAC communication skills procedures and tools provide the best opportunity for individuals who cannot speak for them to communicate with others. However, if these procedures and tools are not used and optimally utilised, they will certainly not bring any benefits. 
It is important for teachers to understand the appropriate teaching skills to the autistic students to start the PdPC session and to understand their learning behaviour while in the classroom. The use of augmentative and alternative communication technique such as swapping of pictures, sign language and gestures during PdPC can be developed through a series of formal training and workshops.

\section{REFERENCES}

Abbeduto, L., Seltzer, M. M., Shattuck, P., Krauss, M. W., Orsmond, G., \& Murphy, M. M. (2004). Psychological well-being and coping in mothers of youths with autism, down syndrome, orfragile $\mathrm{X}$ syndrome. American Journal on Mental Retardation, 109(3), 237-254.

Alexander, J. L., Ayres, K. M., \& Smith, K. A. (2015). Training teachers in evidence-based practice for individuals with autism spectrum disorder: A review of the literature. Teacher Education and Special Education, 38(1), 13-27.

American Psychiatric Association. (2016). Diagnostic and statistical manual of mental disorders. Psychiatric News, 51(9), 1-1.

Cooper, P., \& Simonds, C. J. (2007). Communication for the classroom teacher. 8th ed. United States: Pearson Education, Inc.

Council, N. R. (2001). Educating Children With Austism. (National Academy of Sciences, Ed.) Committee. National Academies Press.

DaFonte, M.A., \& Boesch, M. C. (2016). Recommended augmentative and alternative communication competencies for special education teachers. Journal of International Special Needs Education, 19(2), 47-58.

Ganz, J. B. (2014). Aided augmentative communication for individuals with autism spectrum disorders. Springer.

Hamzah, H. J. N. (2014). Pengurusan Bilik Darjah dan Tingkah Laku. Siri Pendi. Shah Alam, Selangor: Oxford Fajar Sdn. Bhd.

Harding, C., Lindsay, G., O’Brien, A., Dipper, L., \& Wright, J. (2011). Implementing AAC with children with profound and multiple learning disabilities: A study in rationale underpinning intervention. Journal of Research in Special Educational Needs, 11(2), 120-129.

Hasnah, T., Mohd. Hanafi, M. Y., Mohd. Mokhtar, T., \& Norani, S. (2010). Tahap Latihan, Pengetahuan dan Keyakinan Guru-guru Pendidikan Khas tentang Autisme. Malaysian Journal of Education, 35(1), 19-26.
Toran, H., \& Bujang, F. C. (2013). Siri Pendidikan Autisme Pengajaran Berstruktur. Bangi: Universiti Kebangsaan Malaysia.

Hazahamima, M., \& Norshidah, M. S. (2016). Penggunaan Ipad Dalam Menangani Tingkah Laku Mencabar Murid Autisme Spectrum Disorder (ASD) di Bilik Darjah. Seminar Antarabangsa Pendidikan Khas Rantau Asia Tenggara Siri Ke-6, 745-751.

Jang, J., Dixon, D. R., Tarbox, J., \& Granpeesheh, D. (2011). Symptom severity and challenging behavior in children with ASD. Research in Autism Spectrum Disorders, 5(3), 1028-1032.

Kuder, S. J. (2003). Teaching students with language and communication disabilities. Allyn \& Bacon, 75 Arlington Street, Suite 300, Boston, MA 02116.

Creswell, J. W., \& Creswell, J. D. (2017). Research design: Qualitative, quantitative, and mixed methods approaches. Sage publications.

Santrock, J. W. (2011). Educational Psychology. 5th ed. New York: McGraw-Hill Companies Inc.

Light, J. C., \& Drager, K. D. (2002). Improving the design of augmentative and alternative technologies for young children. Assistive Technology, 14(1), 17-32.

Blueprint, M. E. (2013). Malaysia Education Blueprint 2013 - 2025. Education 27(1): 1-268.

Millar, D. C., Light, J. C., \& Schlosser, R. W. (2006). The impact of augmentative and alternative communication intervention on the speech production of individuals with developmental disabilities: A research review. Journal of Speech, Language, and Hearing Research, 49, 48-264.

Ghani, M. Z., \& Ahmad, A. C. (2011). Kaedah dan Strategi Pengajaran Kanak-kanak Berkeperluan Khas (Penerbit USM). Penerbit Usm.

Mustonen, T., Locke, P., Reichle, J., Solbrack, M., \& Lindgren, A. (1991). An overview of augmentative and alternative communication systems. Implementing augmentative and alternative communication: Strategies for learners with severe disabilities, 1-37.

Aini, A. N., \& Hanifah, N.A. (2015). Tahap pengetahuan guru pendidikan khas apabila mengurus tingkah laku murid bermasalah pembelajaran. Asia Pacific Journal Educators and Education, 30(1), 73-88.

Noraini, A., Zamri, M., \& Zahara, A. (2012). Communication Skill Teaching For Severe Learning. Disabilities Pupils. Malay Language Educational Journal, 2(2), 11-18.

Rabi, N. M. (2015). Rahsia Dan Keunikan Personaliti Kanak-Kanak Autistik Di Malaysia (Penerbit USM). Penerbit USM. 
Pilgrim, J., Bledsoe, C., \& Reily, S. (2012). New technologies in the classroom. Delta Kappa Gamma Bulletin, 78(4), 16-23.

Porter, L. (2002). Educating Young Children with Special Needs. British Li. London: Paul Chapman Publishing.

Sakinah, I., \& Nurdin, N. A. (2014). Anak Autisme: Terapi dan Sokongan. (Universiti Teknologi Mara, Ed.). Kuala Lumpur: Percetakan Haji Jantan Sdn. Bhd.

Sigafoos, J., \& Mirenda, P. (2002). Strengthening communicative behaviors for gaining access to desired items and activities, Exemplary practices for beginning communicators. J Reichle, Baltimore: Paul H. Brookes Publishing Co.

Son, S. H., Sigafoos, J., O’Reilly, M., \& Lancioni, G. E. (2006). Comparing two types of augmentative and alternative communication systems for children with autism. Pediatric Rehabilitation, 9(4), 389395.
Subihi, A. S. (2013). Saudi Special Education Student Teachers' Knowledge of Augmentative and Alternative Communication (AAC). International Journal of Special Education, 28(3), 93-103.

Tobergte, D. R., \& Curtis, S. (2013). Characteristics of the Turfgrass industry in 2020: A Delphi study with implications for agricultural education programs. Journal of Chemical Information and Modeling, 53(9), 1689-1699.

Trevarthen, C., Papoudi, D., Robarts, J., \& Aitken, K. (1996). Communicating and playing with an autistic child. Children with autism: Diagnosis and interventions to meet their needs, 98-115.

Zlatanova, S. (2002). Augmented Reality Technology 77. Retreived on http://www.gdmc.nl/publications/ reports/GISt17.pdf. 